\title{
Effects of micronutrients foliar application on rice (Oryza Sativa L. cv. Shiroodi) morphological traits, yield and yield components
}

\author{
Ashkan Daneshtalab Lahijani, Amir Abbas Mosavi*, Morteza Moballeghi \\ (Department of Agronomy, Chalous branch, Islamic Azad University, Chalous, Iran)
}

\begin{abstract}
In order to assess the effect of micronutrients ( $\mathrm{Mn}, \mathrm{Zn}, \mathrm{Fe}, \mathrm{Cu}$ and $\mathrm{B}$ ) on rice metabolism and performance, research implemented in the form of randomized complete block design with 8 treatments (T0 Control, T1-T7 one to seven spraying) with 3 replications. The location of this research was the Rice Research Institution of Iran (Mazandaran) during two consecutive years (2017 and 2018 cultivation seasons). The results demonstrate that the effect of micronutrients foliar application is significant at the $1 \%$ level of probability of some traits such as plant wet weight, 12 plants yield, and leaf area. Also, it is significant at the $5 \%$ level of probability of some traits such as the number of tillers/plant, 80 plants yield, cluster length, leaf color chart and 1000 grains weight. In this relation, the interaction of year*foliar application was significant for the studied traits. The purpose of this study was to evaluation of micronutrients effect on rice plant. Pursuant to the results, it can be significantly concluded that the micronutrients furnish through the leaf application can influence on rice yield and yield components. This event is justifiable by micronutrients role in the plant metabolic procedures and enzymes activation that affects crops vegetative growth and productivity. Furthermore, the postponement time can be decreased by the leaf spraying of the micronutrients and this is vital for rice plant during the rapid growth phase. The results are significantly evident that one leaf spraying of essential micronutrients will impress on rice yield.
\end{abstract}

Keywords: grain yield, foliar application, micronutrients, rice (Oryza Sativa L.)

DOI: $10.25165 /$ j.ijabe.20201301.5272

Citation: Daneshtalab Lahijani A, Mosavi A A, Moballeghi M. Effects of micronutrients foliar application on rice (Oryza Sativa L. cv. Shiroodi) morphological traits, yield and yield components. Int J Agric \& Biol Eng, 2020; 13(1): $217-223$.

\section{Introduction}

The rice (Oryza Sativa L.) is one of the substantial staple meals in the World and Asia, where 90 percent of rice efficiency is being done and consumed in the entire world. China is one of the remarkable rice producers in the World, and more than $1 / 3$ of whole rice production is allotment to this country. Pursuant to rice definitive role in cuisine and calorie security, it maintains a critical position in the Iranian meal supply ${ }^{[1]}$. It is apparent that the increment of rice yield will be attainable by exerting novel agricultural approaches such as intermittent nutritional techniques and, rice pests and diseases management. Due to the actuality that Mazandaran state climate in the North of Iran is temperate, there is an inestimable territorial potential for increasing the content of rice yield and replacing new agricultural operations with the traditional methods. Iran by containing 550 thousand hectares of cultivation area and $2 \mathrm{Mt}$ of rice production, has $0.4 \%$ portion of ecumenical production $^{[2]}$. Compared to current production level which is $480 \mathrm{Mt}$, it's expected that the worldwide solicitation for rice will be around $810 \mathrm{Mt}$ in 2025 , so in order to face this issue, the productivity has to be doubled ${ }^{[3]}$. Unfortunately, in most instances lack of proper perception about rice plant requirements according to the cultivars during vegetative and reproductive stages is considered a remarkable impediment for access to intended expediency.

\footnotetext{
Received date: 2019-07-07 Accepted date: 2019-11-15
}

Biographies: Ashkan Daneshtalab Lahijani, PhD candidate, Agrotechnology (Plant physiology), research interests: agronomy, Email: ashkan.daneshtalab1367@ gmail.com; Morteza Moballeghi, PhD, Crop Ecophysiology, research interests: agronomy and crop ecology, Email: mor.moballeghi@gmail.com.

*Corresponding Author: Amir Abbas Mosavi, PhD, Plant Breeding, research interests: agronomy, Mailing address: Chalous branch, Islamic Azad University, Chalous, Iran. Tel: +981152220020, Email: amirabbasmosavi@iauc.ac.ir.
Essential mineral nutrients are usually arranged as macronutrients and micronutrients according to their pertinent condensations in plant contexture. Classifications of micro vs. macronutrients refer to plant requirements rather than plant absorption quantity and they $\left(\mathrm{Zn}^{+2}, \mathrm{Fe}^{+2} / \mathrm{Fe}^{+3}, \mathrm{Mn}^{+2} \& \mathrm{Cu}^{+2}\right)$ cannot be taken up by plants in their elemental, or non-charged form, but instead are taken up in an ionic form, with the exclusion of boric acid $\left(\mathrm{H}_{3} \mathrm{BO}_{3}\right.$ and $\left.\mathrm{H}_{2} \mathrm{BO}_{3}{ }^{-}\right)$which is uncharged ${ }^{[4]}$. Some of the essential micronutrient biochemical functions that used in this study are: Manganese (Mn) activate several enzymes in plant cells and needed for acting of some dehydrogenases, kinases, oxidases, and peroxidases and it is involved with other cation-activated enzymes and photosynthetic $\mathrm{O}_{2}$ evolvement. Actually, the prime specified role of $\mathrm{Mn}$ is in the photosynthetic reaction through which oxygen is produced from water ${ }^{[5]}$. Zinc ( $\left.\mathrm{Zn}\right)$ is constituent alcohol dehydrogenase, glutamic dehydrogenase and carbonic anhydrase and it is needed for chlorophyll biosynthesis and increases the auxin indoleacetic acid capacity production ${ }^{[5]}$ and affect the cell division in the apical meristem cells in several species. Iron $(\mathrm{Fe})$ involved with chlorophyll assembly and in enzymes for electron conduction (redox reactions) ${ }^{[4]}$. In this role, it is reversibly oxidized from $\mathrm{Fe}^{2+}$ to $\mathrm{Fe}^{3+}$ during electron transition. Copper $(\mathrm{Cu})$ acts as a catalyst for respiration, a component of various enzymes ${ }^{[4]}$ involved in redox reaction like iron. An instance of such an enzyme is plastocyanin, which is involved in electron transfer during the light reactions of photosynthesis ${ }^{[6]}$. Boron (B) is complexed with mannitol, mannan, polymannuronic acid, and other constituents of cell walls. Boron is involved in cell elongation and nucleic acid metabolism. The evidence indicates that Boron plays roles in cell elongation, nucleic acid synthesis, hormone responses, and membrane function.

Foliar application has demonstrated economically prosperous 
mainly tree crops and vines such as kiwi, however it is also used with cereals. Micronutrients applied to the leaves could save a farm when basal soil-applied micronutrients would be too slow to correct a deficiency. In wheat, nitrogen applied to the leaves during the later stages of growth augments the protein content of grains $^{[5]}$. Micronutrients absorption by plant leaves is most impressive when the micronutrients solution remains on the leaf as a thin film. Production of thin film needed that the nutrient solutions be supplemented with surfactant chemicals that decrease surface tension. Micronutrients motion into the plant tissue seems to involve dissemination through the cuticle and uptake by leaf cells. In some cases, discrepancies in texture content between macronutrients and micronutrients are not as grand as indicated in the writings. For instance, some plant tissues, such as leaf mesophyll, have approximately as much iron or magnesium. Frequently elements are agreeable in concentrations greater than the plant's minimum demands. The principal sake of most recognized micronutrient shortages is caused by drastic cropping, loss of fertile topsoil apart from and also detriments of nutrients through leaching ${ }^{[7]}$. Micronutrients deficiency is widely extending in the agricultural fields. Insufficient amounts of trace elements are envisaged in the antiquated prospects in the zones with high precipitation and temperature, and where trace element concentrations in provenance materials are originally skimp ${ }^{[8]}$. The presentment of micronutrient deficiency renders it inconceivable for the plant to gain superlative advantage from primary and secondary macronutrients application. Micronutrients are arranged as effectual elements in the plant metabolism, even if they are applied in little quantity. Plants cannot complete their life cycle in the inexistence of micronutrients ${ }^{[9]}$. Premier system of fertilizer management is necessary for severe cropping on the same segment of a farm with high yielding varieties and it is known that long-term cropping will change the approachability of soil micronutrients ${ }^{[10]}$. Thus, there is an urgent necessity for correcting particular nutrient deficiencies and reducing their further expanse $\mathrm{s}^{[3]}$.

In rice growing territories, the micronutrient leakage is weighed as one of the basic drawbacks of the diminished efficiency, so the single application of particularly NPK cannot be more practical because of continuous elimination of micronutrients after harvesting as well as losses due to leaching or surface floods ${ }^{[11]}$. The micronutrients deficiency not only is determinative factor of crop productivity reduction but also is deteriorating quality. According to the reports ${ }^{[12,13]}$, most of the soils are micronutrient deficient and incapable to aliment crops properly. The foliar sprays have been used for multiple crops for providing micronutrients, especially Fe and Mn. For several decades the micronutrient spraying has been used for crops to ameliorate the rate of yield ${ }^{[14]}$. Considering the importance of micronutrient roles in the plant nutrition and enzyme activation, this investigation has been done on rice (cv. Shiroodi) for evaluating the efficacies of ( $\mathrm{Fe}, \mathrm{Zn}, \mathrm{B}, \mathrm{Cu}$ and $\mathrm{Mn}$ ) integrated foliar application on structural traits, yield and yield components. The main question of this research is, will this approach cause a remarkable influence on rice production? If yes, it will reduce the production costs and enhances the yield significantly through affecting yield components. The critical purposes that will determinative in the field of the human food supply.

\section{Materials and methods}

\subsection{Location and experimental design}

The experiment was conducted at Iran Rice Research Institute farm, Amol, Mazandaran, Iran (52 $3^{\prime} 0^{\prime \prime} \mathrm{N}, 26^{\circ} 28^{\prime} 0^{\prime \prime} \mathrm{E}, 23$ Altitude). Pursuant to meteorological divisions, this region experiences moderate summer, relatively cold and dry winter. Furthermore, the research was implemented during two consecutive cultivation seasons. The first cultivation season was April to August 2017. The experimental rice variety was Shiroodi which was supplied by Iran Rice Research Institute. To survey the effect of micronutrients on rice metabolism, traits indicators, yield, and yield components through leaf spraying with dosage of $1 \mathrm{~L}$ liquid micronutrients fertilizer/1000 L of water and the fertilizer analysis mentioned in Table 1, this investigation was done in the form of the randomized complete block design (RCBD).

Table 1 Micronutrients liquid fertilizer analysis

\begin{tabular}{ccccc}
\hline $\begin{array}{c}\mathrm{Fe}(\mathrm{EDTA}) \\
/ \% \mathrm{w} / \mathrm{w}\end{array}$ & $\begin{array}{c}\text { Soluble B } \\
1 \% \mathrm{w} / \mathrm{w}\end{array}$ & $\begin{array}{c}\mathrm{Zn}(\mathrm{EDTA}) \\
/ \% \mathrm{w} / \mathrm{w}\end{array}$ & $\begin{array}{c}\mathrm{Cu}(\mathrm{EDTA}) \\
/ \% \mathrm{w} / \mathrm{w}\end{array}$ & $\begin{array}{c}\text { Mn (EDTA) } \\
/ \% \mathrm{w} / \mathrm{w}\end{array}$ \\
\hline 0.1 & 0.02 & 0.05 & 0.05 & 0.05 \\
\hline
\end{tabular}

\subsection{Treatments and measurements methods}

The eight treatments (T0 is controlled, T1 to T7 represent one foliar application to seven foliar applications, respectively) were performed with three replications for this trial. The soil samples were randomly collected from eight various spots in each of the experimental plots from 0-30 $\mathrm{cm}$ depth, and after the determination of soil texture, the soil physicochemical features (Table 2) evaluated in the lab. Thus, fertilizer recommendation was provided with considering the soil analysis report. Furthermore, the analysis report indicated that concentration of soil micronutrients did not cause a significant effect on investigation results and the pesticides used in this trial had not micronutrients in their chemical structure.

Table 2 Soil analysis

\begin{tabular}{cccccccccccccccc}
\hline $\begin{array}{c}\text { Depth of } \\
\text { sampling/cm }\end{array}$ & $\begin{array}{c}\mathrm{EC} \\
/ \mathrm{ds} \cdot \mathrm{m}^{-1}\end{array}$ & $\mathrm{pH}$ & $\begin{array}{c}\mathrm{Ca} \\
\text { carbonate/\% }\end{array}$ & $\begin{array}{c}\mathrm{OC} \\
/ \%\end{array}$ & $\begin{array}{c}\text { Absorbable P } \\
/ \mathrm{ppm}\end{array}$ & $\begin{array}{c}\text { Absorbable K } \\
/ \mathrm{ppm}\end{array}$ & $\begin{array}{c}\mathrm{Fe} \\
/ \mathrm{ppm}\end{array}$ & $\begin{array}{c}\mathrm{Zn} \\
/ \mathrm{ppm}\end{array}$ & $\begin{array}{c}\mathrm{B} \\
/ \mathrm{ppm}\end{array}$ & $\begin{array}{c}\mathrm{Cu} \\
/ \mathrm{ppm}\end{array}$ & $\begin{array}{c}\mathrm{Mn} \\
/ \mathrm{ppm}\end{array}$ & $\begin{array}{c}\mathrm{Clay} \\
/ \%\end{array}$ & $\begin{array}{c}\text { Silt } \\
/ \%\end{array}$ & $\begin{array}{c}\mathrm{Sand} \\
/ \%\end{array}$ & $\begin{array}{c}\text { Soil } \\
\text { texture }\end{array}$ \\
\hline $0-30$ & 1.9 & 7.9 & 34 & 2.6 & 2.8 & 96 & 62 & 1.3 & 0 & 7.73 & 7.06 & 30 & 48 & 22 & $\mathrm{Si}-\mathrm{L}$ \\
\hline
\end{tabular}

The pre-planting preparation has been done during early of April 2017. The necessary basal fertilizers (N: $250 \mathrm{~kg} / \mathrm{hm}^{2} 40 \%$ before transplantation $+30 \% 21 \mathrm{~d}$ after transplantation $+30 \%$ during $35 \mathrm{~d}$ after transplantation; P: $150 \mathrm{~kg} / \mathrm{hm}^{2} 100 \%$ before transplantation; K: $200 \mathrm{~kg} / \mathrm{hm}^{2} 50 \%$ before transplantation $+50 \%$ $35 \mathrm{~d}$ after transplantation) applied to soil according to analysis report and rice cultivar recommendation. The first seed cultivation has been done in the seedling site in the middle of April. The transplantation to farm was done manually (traditional method) when the plant's height was $20 \mathrm{~cm}$. The same operation was carried out for the second year. The first leaf spraying has been done $9 \mathrm{~d}$ after transplantation and another foliar application has been done at $7 \mathrm{~d}$ intervals. The field maintenance and use of pesticides were based on standard practices. The data were collected during vegetative (tillering), reproductive (clustering) and harvesting (seed filling) stages for two consecutive seasons. The sampling operations have been done at the middle and end of rice growth stages accidentally.

The traits like plant height, number of tillers/plant, leaf color chart (LCC), plant fresh weight, plant dry weight, number of filled 
seeds/plant, cluster length, leaf area index (LAI), 12 plants yield, 80 plants yield, harvest index and 1000 grains weight have been evaluated in this investigation. The plant samples collected by quadrat $(0.5 \mathrm{~m} \times 0.5 \mathrm{~m})$ and measurements were performed with a caliper. The calculating of 80 plants revenue has been done through elimination of marginal rows, and middle plants considered for sampling operation. Furthermore, 12 plants yield assessed at the same procedure for more confidence during calculation trend and having the backup data for supplementary analysis. The grain moisture was measured by a moisture meter. Plus, the counterpoise of shrubs has been done after sampling immediately for plant wet weight deliberation. In this relation, the plant dry weight has been evaluated by placing the samples in a dryer at $74^{\circ} \mathrm{C}$ for $24 \mathrm{~h}$. The harvest index, calculated through the below equation:

$$
\mathrm{HI}=\text { Biological yield/Economic yield } \times 100
$$

The leaf color chart diagram was used for evaluating of LCC. The leaf color chart diagram is containing four separate sections (dark green to pale green) that determine the leaf greenness and nitrogen content. Because of presence of nitrogen in the chlorophyll ring chemical structure, $\mathrm{N}$ concentration diagnosis is a crucial factor for crop yield determination. In compliance with LCC diagram instruction, it used $14 \mathrm{~d}$ after transplantation and it continued to the end of the clustering stage. Reading the apparatus has been done during from 8:00 to $10: 00$ or 14:00 to 16:00. To avoid making a mistake LCC diagram reading has been done under reader body shadow. For reading the device number, 10 healthy leaves selected randomly. In addition, the highest leaf selected from the shrub for placing on the LCC diagram. The intermediate area of the leaf considered for comparison and then leaf color compared to apparatus color.

\subsection{Data analysis}

The variance analysis has been done at the end of each year, pursuant to experimental design. The curves and diagrams were drawn by Microsoft office word and Excel software. Collected data were subjected to analyze the variances performed utilizing the SAS program to determine the statistical significance of the effect of treatments. When the $F$-value was significant, Duncan test was performed for means comparison.

\section{Results and discussion}

\subsection{Plant height}

The variance analysis revealed the effect of micronutrients treatment was non-significant about plant height (Figure 1). Furthermore, the mean comparison table indicated that the highest plant height belonged to T5 $(122.167 \mathrm{~cm})$ and the lowest amount was related to the control $(113.167 \mathrm{~cm})$. Although the foliar application of micronutrients was non-significant about plant height, it had a tangible influence on treatments that received micronutrients through leaves compared to the control. This subject is explainable according to micronutrients role in plant metabolism. For example, $\mathrm{Zn}$ is constituent of alcohol dehydrogenase, glutamic dehydrogenase and carbonic anhydrase and many enzymes require $\mathrm{Zn}$ ions $\left(\mathrm{Zn}^{2+}\right)$ for their actions, and zinc may be required for chlorophyll biosynthesis in some plants. In addition, in some species, zinc plays a key role in enhancing the Indole Acetic Acid (IAA) secretion ${ }^{[5]}$. In this regard, Zayed et al. ${ }^{[8]}$ reported that the combined application of $\mathrm{Zn}+\mathrm{Mn}, \mathrm{Fe}+\mathrm{Mn}$, and $\mathrm{Fe}+\mathrm{Zn}$ has no significant effect on rice growth under the saline situation either.

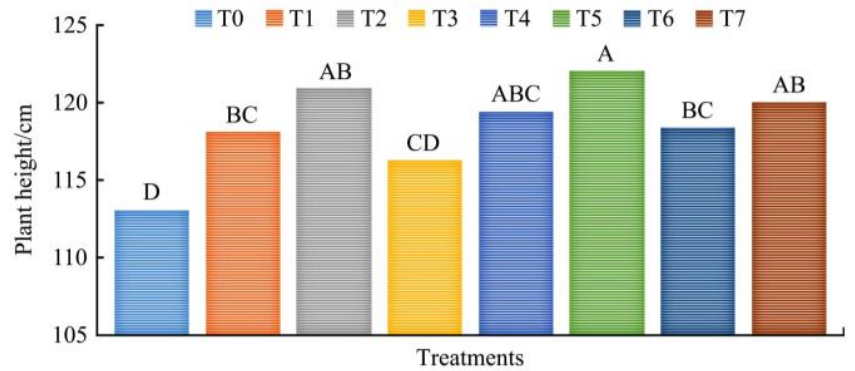

Note: Averages with the same letters have no significant differences.

Figure 1 Effect of micronutrients foliar application on rice (cv. Shiroodi) plant height

\subsection{Number of tillers/plant}

The influence of micronutrients leaf application was significant at the 5\% level of probability on the mentioned trait (Figure 2). Furthermore, the highest number of tillers/plant belonged to T2 (26) with two foliar applications and the lowest rate was related to T1 (21.176). In the same investigation, the results revealed that there is a significant interaction between Shiroodi and Hashemi about tillers/ plant at the level of $1 \%^{[15]}$. Other than the boron, most of the micronutrients are immobile in the soil structure. So, the leaf spraying of these elements can rectify the plant metabolism procedures compared to their soil application. The most important function of manganese is in the photosynthetic reaction when oxygen is produced from water ${ }^{[9]}$. In addition, $\mathrm{Cu}$ is a component of ascorbic acid oxidase, tyrosinase, monoamine oxidase, uricase, cytochrome oxidase, phenolase, laccase, and plastocyanin. Furthermore, like iron, copper associated with enzymes involved in redox reactions being reversibly oxidized from $\mathrm{Cu}^{+}$to $\mathrm{Cu}^{2+[5]}$. For example, one of these enzymes is plastocyanin, which is involved in electron transfer during the light reactions of photosynthesis ${ }^{[6]}$. In addition, Mahmmudi et al. ${ }^{[16]}$ reported that the interaction between $\mathrm{K}$ and $\mathrm{Zn}$ increases the number of tillers/plant significantly.

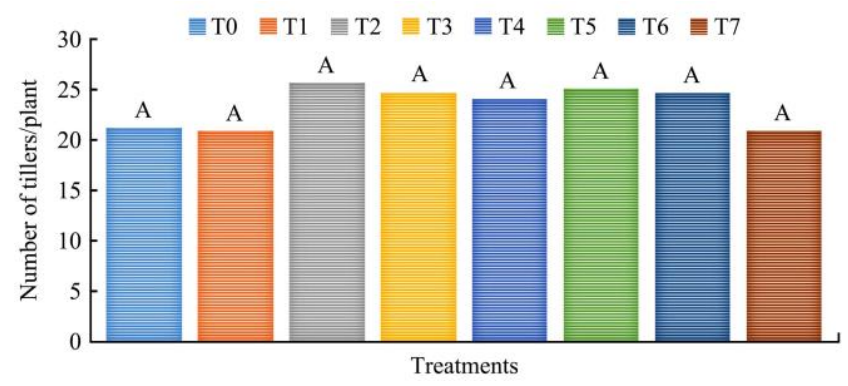

Note: Averages with the same letters have no significant differences.

Figure 2 Effect of micronutrients foliar application on rice (cv. Shiroodi) number of tillers/plant

\subsection{Leaf color chart (LCC)}

The results revealed that the effect of micronutrients leaf spraying was significant at the $5 \%$ level of probability about leaf color chart (Figure 3). The mean comparison (Table 3) showed that the highest number leaf color chart belonged to several treatments such as T1 to T5 (4) and the lowest number was related to T6. The increment of leaves greenness is explainable through foliar application of some essential micronutrients such as Fe that is involved with chlorophyll synthesis and in enzymes for electron transfer ${ }^{[4]}$. Since the Iron is an immobile element in both plant tissue and soil structure, it seems that the leaf spraying of Fe has a designation role on $\mathrm{N}_{2}$ fixation procedure and improvement of leaves greenness due to nitrogen position in the chemical structure of chlorophylls. 
Table 3 Mean comparison

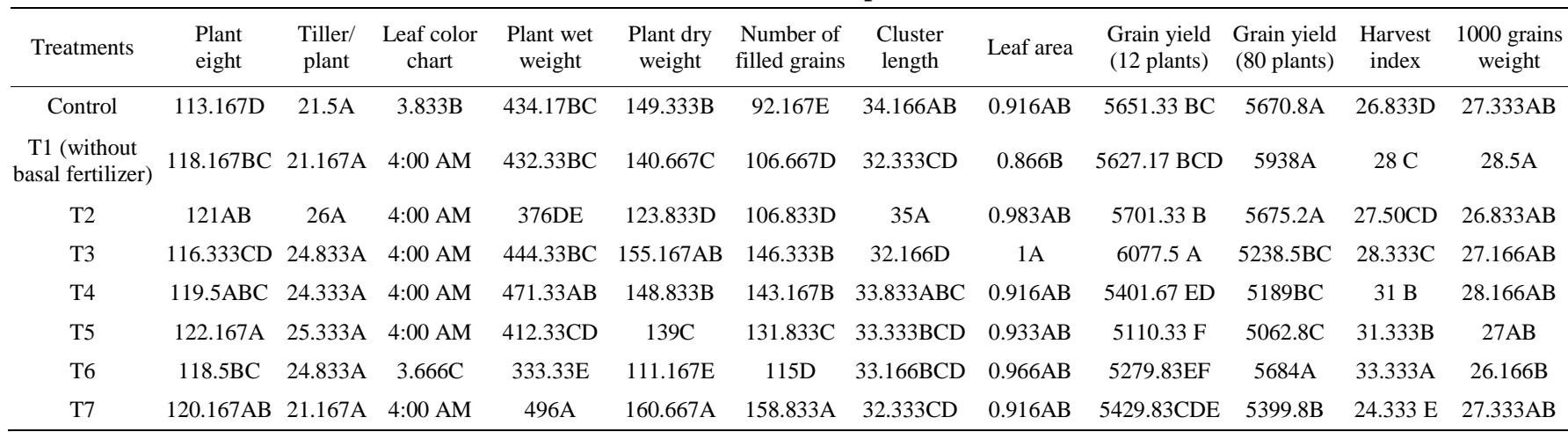

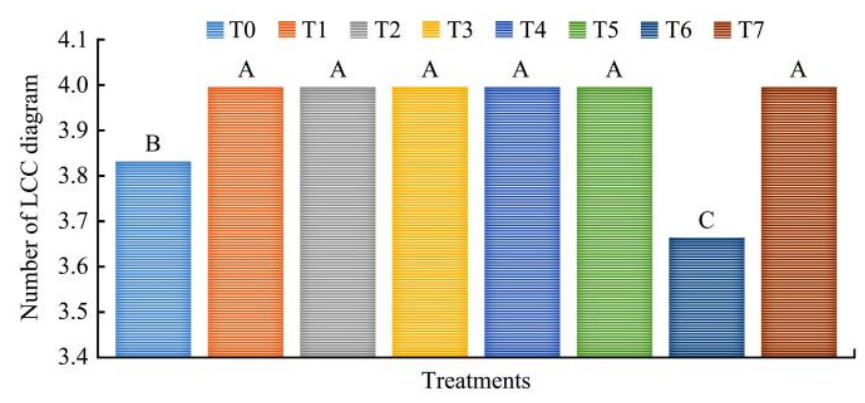

Note: Averages with the same letters have no significant differences.

Figure 3 Effect of micronutrients foliar application on rice (cv. Shiroodi) leaf color chart

\subsection{Plant wet weight}

The data analysis showed that the micronutrients treatments effect was significant at the $1 \%$ level of probability about plant wet weight (Figure 4). The mean comparison table indicated that the highest plant wet weight belonged to T7 (496 g) and the lowest rate was related to T6 (333.33 g). The foliar application can be substantial during the quick growth phase, it can diminish the postponement time between the fertilizer application and uptake by the hair roots. It can also circumvent the issue of constrained uptake of nutrients from the soil. Consequently, micronutrients supply can facilitate rice internal reactions and ameliorate the plant tissues growth rate and plant wet weight, too. In this relation, Najafi Tirtashi et al. ${ }^{[17]}$ reported that it is possible to introduce the micro and macro elements treatments as the appropriate nutritional solution for improvement of rice production and morphological traits indicators. Also, Ghasemi et al. ${ }^{[18]}$ reported the longest cluster length, most of tiller/plant, most of spike/cluster and most 1000 grain weight achieved by zinc sulfate application without $\mathrm{Si}$ and $\mathrm{K}$.

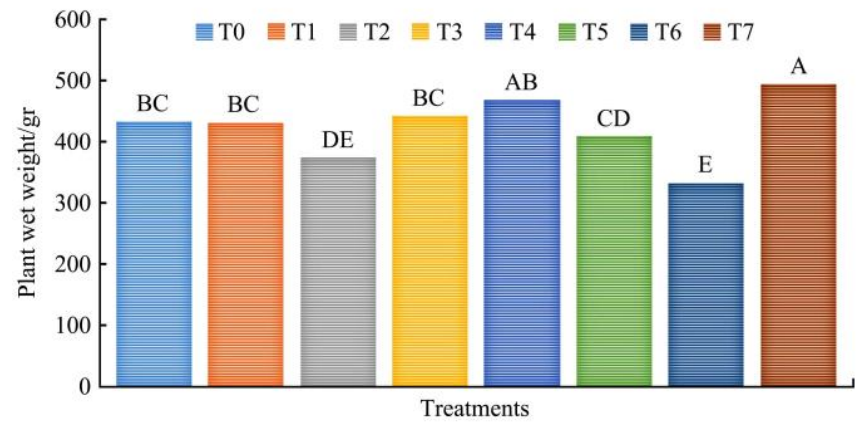

Note: Averages with the same letters have no significant differences.

Figure 4 Effect of micronutrients foliar application on rice (cv. Shiroodi) plant wet weight

\subsection{Plant dry weight}

The plant dry weight was non-significant affected by the micronutrients ( $\mathrm{Zn}, \mathrm{Mn}, \mathrm{B}, \mathrm{Cu}$ and $\mathrm{Fe}$ ) supply (Figure 5). The mean comparison table portended that the highest plant dry weight belonged to T7 (160.667 g) and the lowest amount was related to T6 $(111.167 \mathrm{~g})$. In the same research, it is reported that the micronutrients may affect the wheat seed quality and yield through improvement of growth condition and influence on yield components ${ }^{[19]}$. Under severe $\mathrm{Zn}$ shortage, tillering of the rice will be greatly affected and may be stopped entirely. Zinc deficiency also is known too dramatically increase spikelet sterility in rice ${ }^{[20]}$. Since the micronutrient affects the number of tillers, plant height, and $1000 \mathrm{~g}$ weight pursuant to the similar investigations, consequently these elements will take effect on the plant dry weight through influencing plant growth parameters.

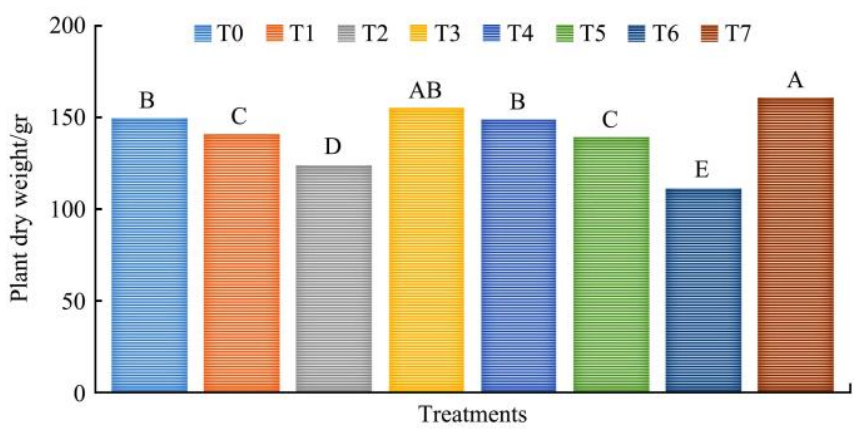

Note: Averages with the same letters have no significant differences.

Figure 5 Effect of micronutrients foliar application on rice (cv. Shiroodi) plant dry weight

\subsection{Number of filled grains/plant}

It is evident from Table 4 that the effect of micronutrients leaf application was non-significant. However, foliar application of micronutrients the highest number of filled grains/plant belonged to T7 (158.833 filled grains) with seven leaf applications, and the lowest amount was related to control (92.167 filled grains) (Figure 6). Consequently, the increment of the number of filled grains/plant in $\mathrm{T} 7$ compared with control and other treatments happened through foliar application of B and $\mathrm{Zn}$. Due to the role of $\mathrm{Cu}$ in plants metabolism, it is the possible integrated foliar application of $\mathrm{Cu}$ and other micronutrients such as $\mathrm{B}, \mathrm{Mn}$, and $\mathrm{Zn}$ facilitate the cluster and seed formation in rice. The plant growth traits such as plant height, number of tillers, dry weight and leaf area index were significantly influenced by the leaf application of zinc and iron in conjunction with age of seedlings ${ }^{[21]}$.

\subsection{Cluster length}

As can be seen in Table 4 the effect of micronutrients foliar application was significant at the $5 \%$ level of probability about cluster length. Furthermore, the mean comparison table indicated that the maximum cluster length was obtained in $\mathrm{T} 2(35 \mathrm{~cm})$ and 
the lowest amount was related to T3 $(32.166 \mathrm{~cm})$ (Figure 7). In the study of spraying time, the results showed that the timing of spraying had a significant effect on flag leaf area, plant height, number of tiller $/ \mathrm{m}^{2}$, number of filled grains/cluster, cluster length, 1000 grain weight, and biological yield. Furthermore, the most yield achieved by spraying for $40 \mathrm{~d}$ after transplantation ${ }^{[15]}$. In another study ${ }^{[22]}$, the utilization of $\mathrm{Zn}$ and $\mathrm{B}$ is reported as the best-balanced fertilizer for higher growth and yield response. The plant height, tillers/plant, panicle length, kernels/plant, productive kernel, straw, paddy, and biological yield increased. Presumably, micronutrients had a great influence on the cluster length due to their functions in plant metabolism. It is like increment of IAA production capacity by $\mathrm{Zn}$ supply through two foliar applications or increase of the enzyme activity due to Mn roles.

Table 4 Variance Analysis

\begin{tabular}{|c|c|c|c|c|c|c|c|c|c|c|c|c|c|}
\hline \multirow{2}{*}{$\begin{array}{l}\text { Source of } \\
\text { changes }\end{array}$} & \multirow{2}{*}{$\begin{array}{l}\text { Degree of } \\
\text { freedom }\end{array}$} & \multicolumn{12}{|c|}{ Mean of Squares } \\
\hline & & $\begin{array}{l}\text { Plant } \\
\text { height }\end{array}$ & $\begin{array}{l}\text { Tiller/ } \\
\text { plant }\end{array}$ & $\begin{array}{l}\text { Leaf color } \\
\text { chart }\end{array}$ & $\begin{array}{l}\text { Plant wet } \\
\text { weight }\end{array}$ & $\begin{array}{l}\text { Plant dry } \\
\text { weight }\end{array}$ & $\begin{array}{l}\text { Number of } \\
\text { filled grains }\end{array}$ & $\begin{array}{l}\text { Cluster } \\
\text { length }\end{array}$ & $\begin{array}{l}\text { Leaf } \\
\text { area }\end{array}$ & $\begin{array}{l}\text { Grain yield } \\
\text { (12 plants) }\end{array}$ & $\begin{array}{l}\text { Grain yield } \\
\text { (80 plants) }\end{array}$ & $\begin{array}{l}\text { Harvest } \\
\text { index }\end{array}$ & $\begin{array}{c}1000 \text { grain } \\
\text { weight }\end{array}$ \\
\hline Block & 2 & 7.312 & 13.270 & 0.062 & 1241.333 & 1135.020 & 849.770 & 0.20 & 0.008 & 1705473.188 & 361020.333 & 4.520 & 1.187 \\
\hline Year & 1 & 5.333 & 0.187 & 0.000 & 2310.187 & 588 & 9.187 & 24.083 & 0.007 & 8008.333 & 111.021 & 0.750 & 9.187 \\
\hline Block (year) & 2 & 14.145 & 13.187 & 0.000 & 525 & 64.937 & 51.937 & 0.645 & 0.004 & 146196.896 & 72939.583 & 1.562 & 0.562 \\
\hline $\begin{array}{c}\text { Foliar application* } \\
\text { year }\end{array}$ & 7 & $5.761^{*}$ & $13.711^{*}$ & $0.000^{*}$ & $1076.568 *$ & $25.904 *$ & $67.949 *$ & $1.2261 *$ & $0.006^{*}$ & $25728.238^{*}$ & $37241.402 *$ & $0.607 *$ & $2.330 *$ \\
\hline error & 28 & 10.395 & 16.229 & 0.269 & 5437.309 & 404.074 & 428.949 & 3.619 & 0.004 & 184344.11 & 245158.22 & 3.375 & 3.660 \\
\hline Coefficient of vari & ation $(\mathrm{CV})$ & 2.718 & 17.037 & 13.180 & 17.351 & 14.248 & 16.555 & 5.714 & 7.406 & 7.757 & 9.031 & 6.371 & 7.005 \\
\hline
\end{tabular}

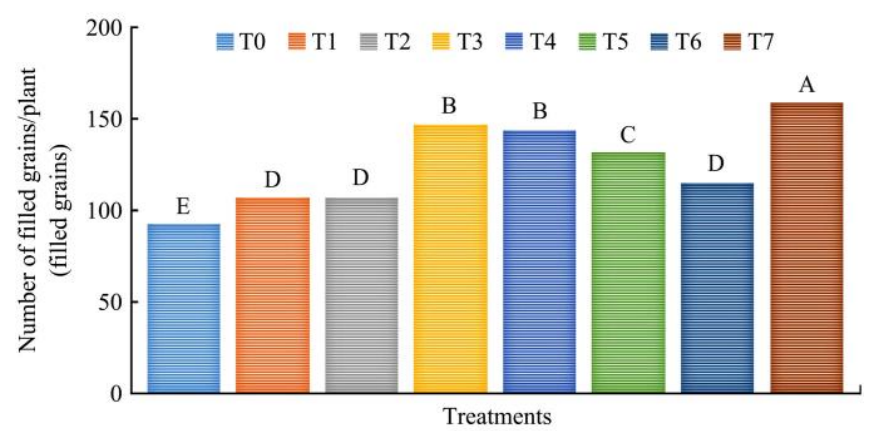

Note: Averages with the same letters have no significant differences.

Figure 6 Effect of micronutrients foliar application on rice (cv. Shiroodi) number of filled grains/plant

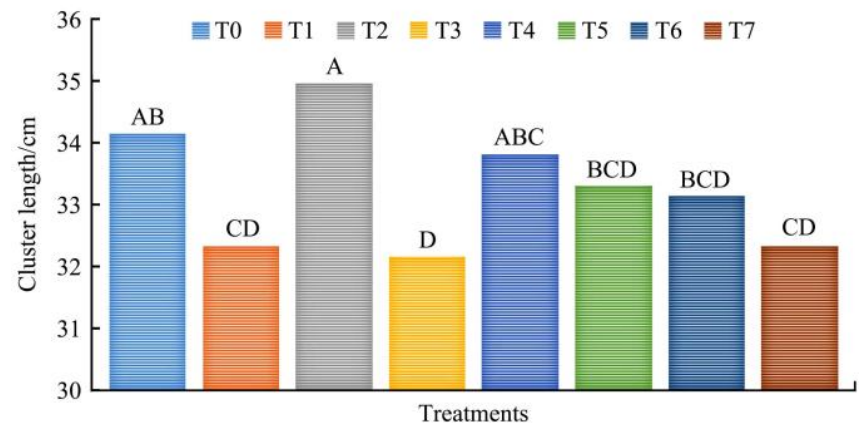

Note: Averages with the same letters have no significant differences.

Figure 7 Effect of micronutrients foliar application on rice (cv. Shiroodi) cluster length

\subsection{Leaf area}

There was a significant variation in leaf area under various micronutrients treatments at the $1 \%$ level of probability. In addition, the results indicated that the highest leaf area belonged to T3 $\left(1 \mathrm{~cm}^{2}\right)$ and the lowest amount was related to T1 $\left(0.866 \mathrm{~cm}^{2}\right)$ (Figure 8). It seems that the foliar application of $\mathrm{Fe}$ that has a critical role in $\mathrm{N}_{2}$ fixation procedure and improvement of leaf area due to nitrogen position in the chemical structure of chlorophylls and other micronutrients such as $\mathrm{Zn}$. It stimulates the plant hormonal activity that was effective on leaf area increasing. These results are in agreement with the findings of the study by Zayed et al. ${ }^{[8]}$.

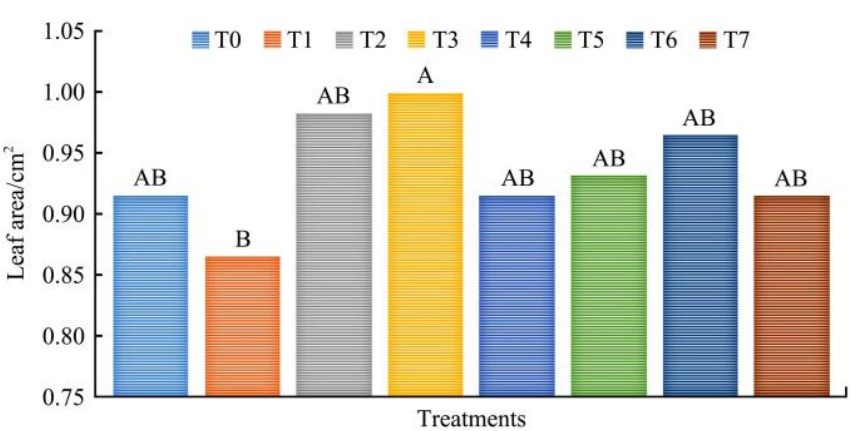

Note: Averages with the same letters have no significant differences.

Figure 8 Effect of micronutrients foliar application on rice (cv. Shiroodi) leaf area

\subsection{Grain yield (12 plants)}

The data regarding the micronutrients leaf spray as influenced by $\mathrm{Zn}, \mathrm{Fe}, \mathrm{B}, \mathrm{Mn}$ and $\mathrm{Cu}$ (Table 4 ) showed that the micronutrients treatments increased grain yield (12 plants) significantly (at the $1 \%$ level of probability) over control. In addition, the mean comparison (Table 3) indicated that the highest grain yield was obtained in T3 $(6077.5 \mathrm{~kg})$ with three foliar applications and the lowest grain yield was related to T5 $(5110 \mathrm{~kg}$ ) (Figure 9). In this relation, there is another report ${ }^{[23]}$ announcing that the application of zinc sulfate $\left(20 \mathrm{~kg} / \mathrm{hm}^{2}\right)$ and boron $\left(4 \mathrm{~kg} / \mathrm{hm}^{2}\right)$ as a significant affecting factor on some traits indices such as plant height, tiller/plant, panicle length, kernels/cluster, 1000 grain weight, biological yield, and harvest index. Furthermore, micronutrients foliar application significantly increased the availability of primary and secondary macronutrients beside some micronutrients such as $\mathrm{Zn}, \mathrm{Fe}, \mathrm{Cu}, \mathrm{Mn}$ and B. Presumably, micronutrients with influence on enzyme activity, plant resistance, carbohydrates assimilation and primary macro elements utilization by the plant, have a significant effect on grain yield.

\subsection{Grain yield ( 80 plants)}

Also, the data on the grain yield ( 80 plants) of rice as influenced significantly (at the 5\% level of probability) by the various number of micronutrients application to leaves. In addition, the results indicated that the highest grain yield belonged to $\mathrm{T} 1 \quad\left(5938 \mathrm{~kg} / \mathrm{hm}^{2}\right)$ with three foliar applications and the lowest rate of grain yield was related to T5 $\left(5062 \mathrm{~kg} / \mathrm{hm}^{2}\right)$ (Figure 
10). Consequently, pursuant to 12 and 80 plants grain yield analysis results, it seems that the micronutrients leaf application increased the rice production significantly compared to control and has a great influence on cluster formation and seed production, but there is no significant difference in the field of the number of spraying between $\mathrm{T} 1$ and $\mathrm{T} 3$ treatments. These results are in agreement with the findings of the study of Furoharnia et al. ${ }^{[24]}$

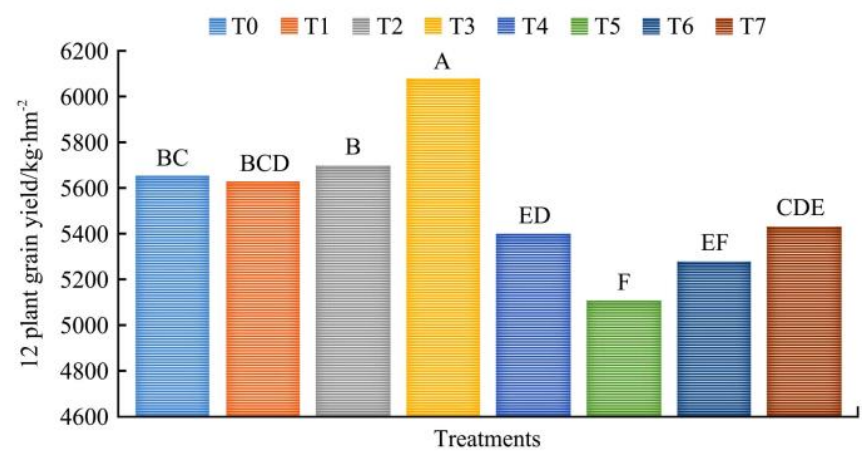

Note: Averages with the same letters have no significant differences.

Figure 9 Effect of micronutrients foliar application on rice (cv. Shiroodi) grain yield (12 plants)

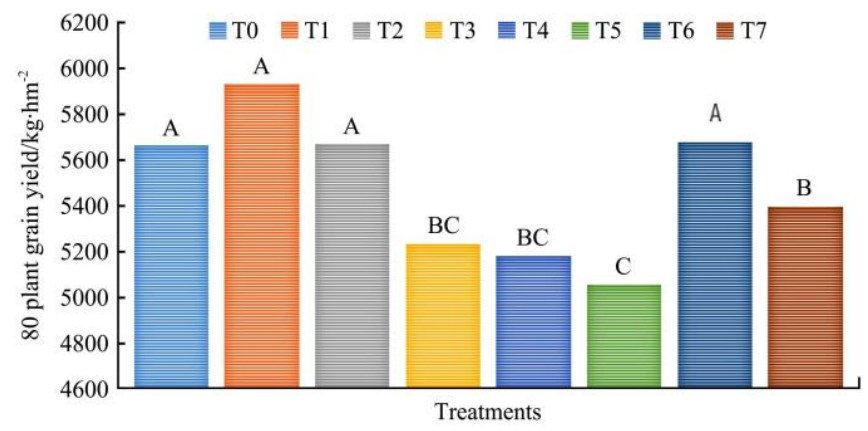

Note: Averages with the same letters have no significant differences.

Figure 10 Effect of micronutrients foliar application on rice (cv. Shiroodi) grain yield (80 plants)

\subsection{Harvest index}

The results presented in Table 4 indicate that application of recommended levels of micronutrients has not significantly enhanced the harvest index. However, the mean comparison (Table 3) proved that the highest harvest index was obtained in T6 (33.333\%) with six foliar applications, and the lowest rate was related to control $(26.833 \%)$ (Figure 11). The increasing in the rate of micronutrients treatments compared to the control harvest index is explainable, because of $\mathrm{Fe}, \mathrm{Cu}, \mathrm{Zn}, \mathrm{B}$ and $\mathrm{Mn}$ roles in plant metabolism and their influence on plant growth indices, however, this difference was non-significant. In this relation, it is reported that the effect of zinc, boron, and copper leaf spraying on wheat was significant on the number of spikes/plant, grain/spike, grain $/ \mathrm{m}^{2}$, harvest index, and grain yield ${ }^{[25]}$. Furthermore, in the similar investigation ${ }^{[21]}$, it is reported that the higher harvest index might be due to better sources to sink translocation of carbohydrates resulted in higher grain and less straw production.

\subsection{Thousand grain weight}

A significant (at the 5\% level of probability) increase in the 1000 grain weight of rice was noticed over the control due to application of micronutrients through leaf (Figure 12). In addition, the results of Table 3 proved that the highest 1000 grain weight belonged to $\mathrm{T} 1(28.5 \mathrm{~g})$ with one foliar application and the lowest 1000 grain weight was related to T6 $(26.166 \mathrm{~g})$. It is possible that $\mathrm{Fe}$ and $\mathrm{Mn}$ functions in plant metabolism during clustering, cluster inoculation, and seed maturation were determinative for successful grain production in rice. These results are in agreement with the findings of Mahmed et al. ${ }^{[26]}$ Also, the results evident that one foliar application of essential micronutrients will influence on rice 1000 grain weight significantly.

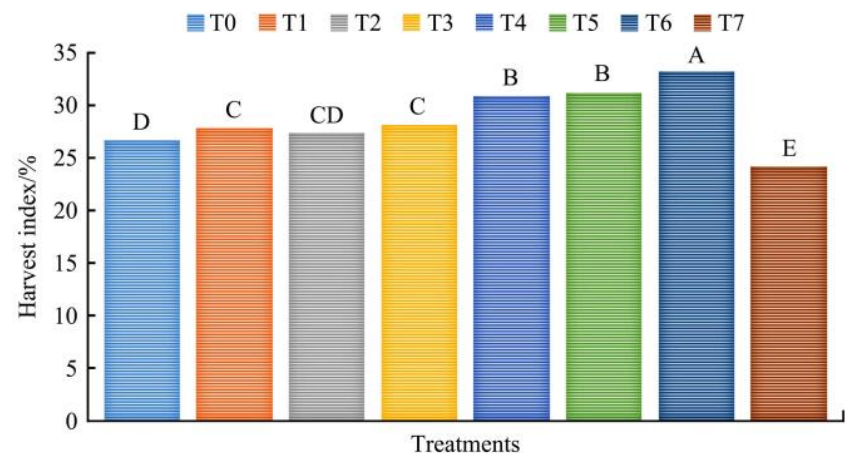

Note: Averages with the same letters have no significant differences.

Figure 11 Effect of micronutrients foliar application on rice (cv. Shiroodi) harvest index

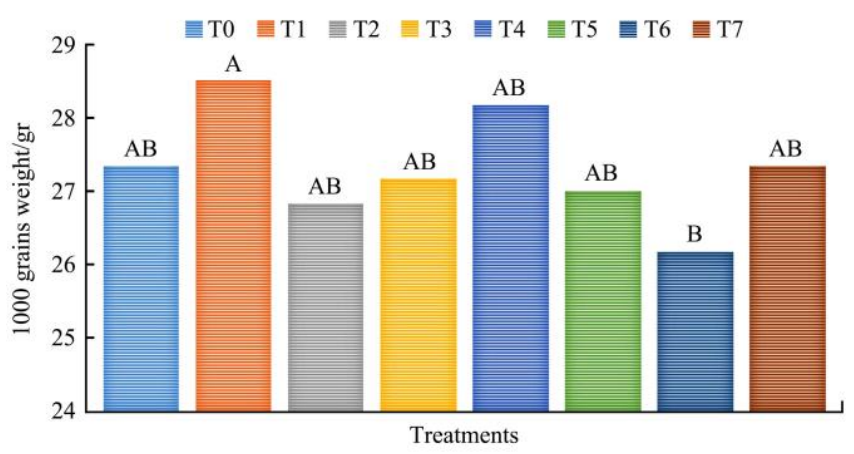

Note: Averages with the same letters have no significant differences.

Figure 12 Effect of micronutrients foliar application on rice (cv. Shiroodi) 1000 grain weight

\section{Conclusions}

The factual findings of this comprehensive study have sufficiently shown foliar application of essential micronutrients $(\mathrm{Fe}$ $\mathrm{Zn}, \mathrm{B}, \mathrm{Cu}$ and $\mathrm{Mn}$ ) positively enhanced rice production under field situation. The observed increases in yield were due to higher rate of the economic yield, number of filled grain/cluster, and additional 1000 grain weight. According to the results, it can be reasonably concluded that the micronutrients supply through the leaf can influence rice ( $c v$. Shiroodi) yield and yield components significantly. This notable event is justifiable by considering the micronutrients role in the plant metabolism and activation of critical enzymes. The foliar application of micronutrients can instantly reduce the lag time between application and nutrients uptake by the plants root system, which can be considered as an important factor during active phase of rapid growth. It can also circumvent the fundamental problem of restricted uptake of micronutrients from soil and the results evident that one leaf spraying of essential micronutrients will impress on rice yield significantly.

This research is applicable under various farm situations, different formulation of liquid or solid micronutrient fertilizers with novel rice varieties for further examination of essential element effects on rice plant morphological and physiological indicators. The local infrastructure constraints like more accurate measurement apparatuses and well-educated human resources are crucial factors for further successful assessments. 


\section{[References]}

[1] Iran Rice Research Institute. Developments in the country's rice production through high-yielding cultivars. IRRI, Gilan, Iran, 2015.

[2] International Rice Research Institute (IRRI). Standard evaluation system for rice. IRRI, Manila, Philippines, 2002.

[3] Radhika K, Hemalatha S, Maragatham S, Praveenalathrine S. Effect of foliar application of micronutrients on the yield components of rice and soil available micronutrients status. An. Asian. J. Soil. Sci., 2013; 2(8): 419-421.

[4] Jones C, Olson-Rutz K. Plant nutrition and soil fertility. Montana. St. Uni. Nutrient Management Module, 2016; 2: 4449-4452.

[5] Taiz L, Zeiger E. Plant physiology, 5th ed. Sinauer Associates, Sunderland, England, 2011.

[6] Haehnel W. Photosynthetic electron transport in higher plants. Annu. Rev. Plant Physiol, 1984; 35: 659-693.

[7] Somani L, Laddha K C, Dadhich S. Micronutrients for soil and plant health. Ag. tech. Pub. Aca. India, 2008; 59-67.

[8] Zayed B A, Salem A K M, El Sharkawy H M. Effect of different micronutrient treatments on Rice (Oriza sativa L.) growth and yield under saline soil conditions. World. J. Agri. Sci., 2011; 7(2): 179-184.

[9] Marschner H. Mineral nutrition of higher plants, 2nd ed. Academic Press, London, England. 1995

[10] Wei X R, Hao M D, Shao M, Gale W J. Changes in soil properties and the availability of soil micronutrients after 18 years of cropping and fertilization. Soil and Tillage Res., 2006; 91: 120-130.

[11] Liew Y A, Syed Omar S R, Husni M H A, Zainal A M A, Nur Ashikin P A. Effects of foliar applied copper and boron on fungal diseases and rice yield on cultivar MR219. Pertanika J. Trop. Agric. Sci., 2012; 35(2): 339-349.

[12] Khattak J K. Micronutrients in Pakistan agriculture. Agri. Res. Coun. Islamabad and NWFP Agri. Uni., 1995; 135p.

[13] Zia M S, Aslam M, Ahmad N, Cheema M, Shah A, Leghari H. Diagnosis of plant nutrient disorders in fruit plants. Proc. plant nutrition management for Horticultural crops under water stress conditions. Agri. Res. Inst. Sariab, Quetta, 2004; pp.16-27.

[14] Savithri. Effect of $\mathrm{MnSo}_{4}$ spray on the field of cotton kapas var. MCU 9 Annual Report, 1980; 135

[15] Hosseinzade S H, Dastan S, Moballeghi M, Bakhshi pour S, Sheykh Ashkevari A. Effects of amounts and timing of foliar application of micronutrients on Rice (Oryza Sativa L.) cultivars yield and yield components. The 15th National Rice Congress, Gen. Agri. biotech. Inst. of Tabarestan, 2012. www.rice15th.sanru.ac.ir.

[16] Mahmmudi J, Sharafi S, Tanha M, Hassanzade R. Effect of $\mathrm{Zn}$ and K elements on yield and yield components of rice (Oryza Sativa L.) cv. Tarom Hashemi. IJFAS Journal, 2015; 4(1): 1-5.

[17] Najafi Tirtashi A, Mahmmudi M, Barari Tari D. Survey effect of foliar application of nutrients on Rice (Oryza Sativa L.) morphological traits and yield. The Crop Ecophysiology Sci. Mgz, 2016; 8(3): 295-303.

[18] Ghasemi M, Mobaser H, Asadi Manesh H, Gholi Zade A. Survey effects of $\mathrm{K}, \mathrm{Zn}$ and $\mathrm{Si}$ on rice (Oryza Sativa L.) yield components and their absorption by seed, 2014. http://ejsms.gau.ac.ir.

[19] Hossein Abadi A, Galuy M, Heydari M. The study effect of foliar application of $\mathrm{Fe}, \mathrm{Zn}$ and $\mathrm{Mn}$ on Wheat quantitative and qualitative characteristics in Hamoun, Sistan region. The new Agri. findings, first year, No. 2. 2006

[20] Dobermann A, Fairhurst T. Rice -Nutrient disorder and nutrien management, 1st ed. Potash \& Phosphate Institute, Los Baños, Laguna, IRRI and Singapore, 2000.

[21] Singh A K, Singh V. Effect of foliar application of iron, zinc and age of seedlings on growth and yield of rice (oryza sativa L.). Int. J. Curr. Microbiol. App. Sci., 2018; 7(8): 1062-1068.

[22] Arif M, Asif Shehzad M, Bashir F, Tasneem M, Yasin G, Iqbal M. Boron, zinc and microtone effects on growth, chlorophyll contents and yield attributes in rice (Oryza sativa L.) cultivar. AJOB, 2012; 11(48): 10851-10858.

[23] Mahendra Kumar M B, Subbarayappa C T, Ramamurthy V. Effect of graded levels of zinc and boron on growth, yield and chemical properties of soils under Paddy. Int. J. of Current Microbio. and Applied Sci., 2017; 6(10): 1185-1196.

[24] Furoharnia D, Moafpurian G, Dehghan H. Survey effect of foliar application of micro mineral fertilizer (without B) on rice (Oryza Sativa L. cv. Shafagh) yield in Roodbal, Estahban, Fars region. 2010. https://www.civilica.com/Paper-AGRIDEA05-AGRIDEA05_609.html.

[25] Jafari Moghadam M, Heidari Sharifabad H, Noormohamadi G, Sadeghian Motahar S Y, Siadat S A. The effect of zinc, boron and copper foliar application, on yield and yield components in wheat (Triticum aestivum). Scho. Res. Lib. Annals of Bio. Res., 2012; 3(8): 3875-3884.

[26] Manal F M, Thalooth A T, Khalifa R K M. Effect of foliar spraying with uniconazole and micronutrients on yield and nutrients uptake of wheat plants grown under saline condition. Journal of American Science, 2010 6(8): 398-404. 